\title{
Autonomy in Leadership: A Case Study of the Founder's Role in Establishing an Organization
}

\author{
Sandro Serpa ${ }^{1}$ \\ ${ }^{1}$ Department of Educational Sciences (DCE), University of the Azores, Ponta Delgada, Azores, Portugal; \\ Interdisciplinary Centre of Social Sciences (CICS.NOVA), Ponta Delgada, Azores, Portugal \\ Correspondence: Sandro Serpa, Department of Educational Sciences (DCE), University of the Azores, Campus \\ de Ponta Delgada, Apartado 1422, PT - 9501-801 Ponta Delgada, Azores, Portugal. Tel: 351-29-665-0000. Fax: \\ 351-29-665-0035. E-mail: sandroserpa@uac.pt
}

Received: December 23, 2014 Accepted: February 5, 2015 Online Published: May 16, 2015

doi:10.5539/ass.v11n13p212 URL: http://dx.doi.org/10.5539/ass.v11n13p212

\begin{abstract}
The extent of a leader's autonomy in establishing organizational culture is a complex issue in organizational studies. The present research analyzed the actions of the founding leader of Asilo de Infância Desvalida da Horta from 1858 to 1879 to determine the extent of his autonomy during his administration using documents in organization archives, local newspaper articles of the period and papers on this topic. The results revealed that the leader's actions did not occur in isolation but were influenced by the sociohistorical environment. Establishing legitimacy as a leader was a complex, multidimensional process that required consideration of the social, legal, regulatory, political and religious aspects of his actions. Although the current research is a case study, the findings suggest that autonomy based on legitimacy is a key element contributing to founder success.
\end{abstract}

Keywords: administration, Asilo de Infância Desvalida da Horta, autonomy in management, educational organization with boarding schools, establishment of organizational culture, founding leader, organizational leadership, Portugal

\section{Introduction}

Although experts acknowledge that organizational culture exhibits regular and predictable patterns and involves shared ways of feeling, thinking and doing that are apprehended, interpreted, produced and reproduced over time by group members, they have not yet reached a consensus with respect to the role of the founding leader in shaping organizational culture.

Expert discussion seems to range along a continuum, with the founder exerting maximum influence at one extreme and minimal influence at the other with respect to the formation of: "artefacts", which include visible structures and processes such as architecture, language, technology and products, clothing, routines, visible behavior patterns, myths, stories, rituals and ceremonies; "espoused beliefs and values", which consist of strategies, objectives and organizational philosophies; and "underlying assumptions" regarding fundamental aspects of life such as the nature of reality, truth, time, space, human nature, human activity and human relations that are shared, "taken-for-granted", preconscious or unconscious, nonnegotiable, and indisputable, which provide a rationale for the other visible aspects of the organization (Schein, 2004, 2010).

Generally speaking, there are two approaches. The first approach, which is prescriptive and pragmatic, focuses on the use of culture (particularly by leaders, executives and managers) as an instrument that is manipulated to resolve an organization's practical problems. Despite differences among its proponents, this mainstream approach stresses the integrating function of organizational culture and its importance in increasing efficiency and productivity. This view predominates in studies of organizational culture in the area of organization and human resources management and administration. This perspective is utilitarian and seeks to explain what happens and why things occur in an organization in terms of relationships between variables with the goal of identifying, assessing, and improving organizational functioning by manipulating the organizational culture. The term "corporate culture" (or culture of the corporation) is widely used in studies that emphasize the integration and cohesion provided by the strong and homogeneous organizational cultures that are primarily found in business and industrial contexts and is associated with prescriptive analyses that focus on managing or manipulating organizational culture. In certain circumstances, this approach employs the term "corporate 
culture" as a synonym for organizational culture and uses the designation "business culture" to refer to company and entrepreneurial cultures. Research adopting a prescriptive orientation that focuses on increasing the efficiency of organizational culture tends to focus on industry and businesses, although in Portugal this approach has increasingly been applied to other areas such as school administration. In contrast, the interpretative approach primarily focuses on analyzing what, how and why events occur in an organization in terms of the interactions between all organizational actors with their inherent discontinuities. Despite differences among its proponents, this approach proposes that organizational culture is not as inclusive and homogeneous as the prescriptive approach assumes and that various cultures coexist within the same organization.

To identify the factors influencing the establishment and modification of organizational culture, Smircich (1983) distinguished two orientations that continue to be relevant: organizational culture seen as a "variable" that is external or internal to the organization (the organization having a culture) or organizational culture considered as a "metaphor" (the organization being a culture). In the former view, organizational culture is based on factors that are internal or external to the organization and can be objectively quantified and directly manipulated, e.g., by the administration as a management tool. In the latter view, the culture of the organization is based on the active role of individual and group actors in establishing and configuring organizational culture, which highlights the unpredictability of the effects of internal or external factors on the organization and the contribution of each organization member to managing the culture.

In comparing the perspectives of culture as variable and culture as metaphor, Smircich (1983) notes that "when culture is a root metaphor, the researcher's attention shifts from concerns about what do organizations accomplish and how may they accomplish it more efficiently, to how is organization accomplished and what does it mean to be organized?" (p. 353).

With respect to the importance of leadership in cultural configurations and reconfigurations, Schein (2004) identifies the close relationship between the actions of the founder/leader and the culture of the organization, which function as "two sides of the same coin" (p. 10), particularly in the early stages of the establishment of the organization:

I believe that cultures begin with leaders who impose their own values and assumptions on a group. If that group is successful and the assumptions come to be taken for granted, we then have a culture that will define for later generations of members what kinds of leadership are acceptable. The culture now defines leadership (2004, p. 2).

For Schein, "cultures basically spring from three sources: (1) the beliefs, values, and assumptions of founders of organizations; (2) the learning experiences of group members as their organization evolves; and (3) new beliefs, values and assumptions brought in by new members and leaders" (2004, p. 225). However, the central leader is the catalyst for cultural creation and change because "it is within the power of leaders to enhance diversity and encourage subculture formation, or they can, through selection and promotion, reduce diversity and thus manipulate the direction in which a given organization evolves culturally" (p. 317).

Schein (2010) highlights the central role and influence of the founding leader in establishing the culture of an organization, stating that "by far the most important for cultural beginnings is the impact of founders" (p. 219), which is consolidated by the group's success in internal integration and external adaptation.

The present research seeks to improve understanding of the founding leader's autonomy in shaping organizational culture by performing a management biography of the founder of Asilo de Infância Desvalida da Horta in Portugal.

\section{Methodology}

The methodology employed in the present research involved an interpretative diachronic organizational case study of an educational institution, which focused on the limits imposed on the autonomy of the organization's founding leader, Father João Pedro d'Ávila during the period from 1858 to 1879 . To identify the extent of the leader's autonomy in establishing the organizational culture, the present study focused on identifying the scope of action of the official founder in administering Asilo de Infância Desvalida da Horta.

The present research was based on obtaining information by collecting, selecting and analyzing internal documents found in the organization's archives, which primarily consisted of statutes, internal regulations, and correspondence, as well as news items in a local newspaper and other documents on the Asylum (Bardin, 1995). With respect to news articles, the newspaper $O$ Fayalense (a weekly newspaper published from 01/04/1857 to 20/01/1895) in the National Library of Portugal was consulted based on the dates available copies for continued direct consultation for two time periods: from December 5 to January 15 (the anniversary of the Asylum's opening) and from April 15 to July 15 (the festival of Santo António, the Patron of the Asylum). 


\section{The Legitimacy of the Founding Leader of Asilo de Infância Desvalida da Horta in Establishing the Organizational Culture}

The goal of Asilo de Infância Desvalida da Horta, which was established in 1858 in Horta, Faial Island, Azores, Portugal, was to provide aid and shelter to impoverished young women and girls.

Father João Pedro d’Ávila was closely connected to Asilo de Infância Desvalida da Horta, serving as its President from 1858 to 1879 and collaborating in establishing a "Religious and Domestic Culture", which is broadly defined as an educational culture rooted in Catholic morality that sought to mold its students into honest married women, mothers, believers and domestic workers. This culture occurred in a precarious financial context that was initially primarily dependent on private funding and maintaining good relationships with the Civil Governor, who regularly issued normative guidelines and proposals regarding the actions of the administrative board. The need required the institution to maintain contact with the external environment, which might include occasions that involved increased contact of asylees with the outside environment.

On January 28, 1858, António José Vieira Santa Rita, the Civil Governor of the District of Horta, who had previously established the Asilo de Mendicidade da Horta in 1843 (Lima, 1981, p. 587), appointed a new committee that chose Father João Pedro d'Ávila as its President. The committee was tasked with creating a Brotherhood that would administer both the Church and the old Convent of Santo António and its surrounding lands, as well as establishing a home for children in need at the location. The committee succeeded in its task. On December 28, 1858, the feast of Santos Inocentes (Holy Innocents) in the Catholic Church calendar, Asilo de Infancia Desvalida da Horta opened with the approval of the "island's leading figures", which included the Civil Governor; six girls between the ages of four and nine years were admitted (Historical Memory of Azylo D'infancia Desvalida da Cidade da Horta, 1884, p. 20).

\subsection{The Need for Social and Religious Legitimacy in Addition to Official Relationships with the External Environment}

Economic conditions after the opening of Asilo de Infância Desvalida da Horta were difficult and a cause for considerable concern. The operation of the Asylum was precarious because it was initially dependent on private funding and on maintaining a good relationship with the Civil Governor of the District of Horta, who issued normative guidelines, provided some financial support and appointed the President, as well as regularly proposing suggestions for Administrative Board actions. The need to maintain good relationships with the external environment involved providing specific occasions for contact with the outside that included a higher although controlled - level of outside contact with the asylees to foster a positive image of the organization (Serpa, 2013).

Institutional contacts with the external environment illustrate the desire to establish the legitimacy of the organization during the initial establishment of the Asylum. On April 25, 1859, the Administrative Committee of the Asylum sent a notification to the Bishop of the Azores, Friar Estevão de Jesus Maria, stating that establishing the Asylum was "a duty, imposed by the sacred Council of Trent (session 22a, Ch. 8)", and requesting his "episcopal approval" (Notification to the Bishop Friar Estevão de Jesus Maria of the Asylum's establishment, in Record of Letters received at Asylo de Infância Desvalida. From 1858 to 1862), which illustrates the direct and indirect influence of the Catholic Church on the Asylum. In his response to this letter, which was dated May 20, 1859 (Reply from the Bishop to the notification of the Committee in charge of establishing an Asylum for Children in Need, in Record of Letters received at Asylo de Infância Desvalida. From 1858 to 1862), the Bishop blessed the Brotherhood (Historical Memory on Azylo D'Infancia Devalida da Cidade da Horta, 1884, pp. 15-16). Thus, the Asylum received religious legitimacy prior to its legal incorporation.

The institutional incorporation occurred in 1860. Both internal and external legal legitimacy were established through the approval of the Statutes of 1860, the appointment of the President by the Civil Governor of Horta and the instatement of the first Administrative Board as a result of the election by the Brothers of Confraria de Santo António de Pádua e Asilo da Infância Desvalida da cidade da Horta.

The President explicitly referred to the institution's incorporation in a letter addressed to a prominent benefactor during this period (Notification to a benefactor of the status of the Asylum with appreciation of a donation, January 7, 1861, in Record of Letters received at Asylo de Infância Desvalida. From 1858 to 1862).

In summary, during the period of institutional incorporation, several factors influenced the actions of Father João Pedro d'Ávila: the need to identify funding sources; the relationship with the Civil Governor and the need to respect his preeminent role in the internal affairs of the Asylum; maintaining a positive public image; and the need to establish religious, legal and managerial legitimacy through his appointment as President by the Civil 
Governor and the instatement of the Administrative Board.

\subsection{Normative Organizational Legitimacy in Asilo de Infância Desvalida da Horta}

Legal legitimacy was conferred with the approval of the first Statutes. With respect to the legal framework for Asilo de Infância Desvalida da Horta, after the Decree of April 25, 1860, the first Statutes were approved on May 9, 1860 by a Royal Letter from King Dom Pedro V, approximately a year and a half after the Asylum opened - Statutes of Confraria de Sto. Antonio e Azylo de Infancia Desvalida da cidade da Horta (henceforth 1860 Statutes) (Statutes of Confraria de Sto. António e Azylo de Infância Desvalida. January 10, 1876).

The official organization chart in the 1860 Statutes identified the Brotherhood Churchwarden as the individual with the most authority, who was granted extensive powers. "[T]he churchwarden is the chief individual with immediate responsibility for administration of the brotherhood, and in particular, towards the Civil Government for the conservation of the convent and its belongings" (Ch. 6, Article 44), and he "is appointed president of all the boards, and can only be dismissed by a special Civil Permit issued by the Civil Governor" (Ch. 6, Article 45).

The President's responsibilities were:

1) To collect and dispense the income of the Brotherhood.

2) To manage and supervise the Asylum.

3) To appoint, suspend and dismiss any nonelected Brotherhood employees.

4) To address and sign all correspondence and represent the Brotherhood in all public acts, regardless of their nature.

5) To execute and enforce board resolutions of a definitive nature.

6) To chair the general assemblies of the Brotherhood (1860 Statutes, Ch. 6, Article 46).

The scope of the Churchwarden's responsibilities required the following caution: "In performing his duties, the churchwarden will scrupulously observe these responsibilities and the regulations established by law, and he may not, by his own action or resolution, change the rules that are prescribed" (Ch. 6, Article 47).

The Statutes explicitly noted the importance of the written rules and regulations framing the organization's operation, stating that "the management, operations and policing of the Asylum for Children in Need will be made in accordance with Article 51" (Ch. 9, Article 58). Further, "[a] regulation prepared by the board will specify in detail how the churchwarden and the board are to perform their different functions", and this regulation required the approval of the Civil Governor (Ch. 7, Article 55, §1, §2).

Based on the statutes and regulations, the President was regarded as the face and the head of the Asylum, with supervisory functions that included managing income and accounting for revenue; management functions that included the operation of the Asylum as well as supervising and proposing modifications for its improvement; representing the Asylum both internally and externally; executive functions with respect to Administrative Board decisions; and control functions that included responsibility for regulatory and statutory compliance.

\subsection{Limits to the Founding Leader's Autonomy}

The following episode illustrates the limits imposed on the legitimacy of actions of the founding leader.

One of the primary protagonists in the establishment and opening of the Asilo de Infância Desvalida da Horta during the period from 1858 to 1879 was Father João Pedro d'Ávila, who was "the main founder and promoter of the asylum" (Historical Memory on Azylo D'Infancia Desvalida da Cidade da Horta, 1884, p. 4) and served as President until 1879. His preeminent status among benefactors of the Asylum and service to the organization was reflected in descriptions such as the following: "the fiscal churchwarden and president of the committee, reverend João Pedro d'Ávila, who has been tireless in promoting the progress of this establishment" (Macedo, 1981, p. 259).

In 1884, an unsigned pamphlet appeared that sought to "do justice" to Father d'Ávila (Historical Memory on Azylo D'Infancia Desvalida da Cidade da Horta, 1884). According to the pamphlet, Father d'Ávila played a central role in the successful and swift recovery of the Church of Santo António's Convent after May 1845, served as chaplain of the church and was chosen to chair the Committee charged with establishing the Asylum, and "the immediate facts illustrated the zeal and activity of the illustrious committee, which established and opened the Children's Asylum of Horta in the same year, on December 28, 1858" (p. 4).

Also in 1860, his services were praised by the Civil Governor Santa Rita, in his response to the notification of the first election of the Asylum's Board of Directors: 
On this occasion, I must declare to Your Excellency that I have rendered due consideration to the relevant services rendered by the Founding Committee of the Children's Asylum of this city, and thank you for the commitment and zeal that you have always shown for this pious task (Reply of the Civil Governor to the notification of the first Administrative Board's election, July 28, 1860, in Record of Letters received at Asylo de Infância Desvalida. From 1858 to 1862).

However, on March 22, 1864, Father João Pedro d'Ávila resigned as President. The pamphlet claimed that this event was due to "unfair accusations, which were made soon after the establishment of the asylum [...] envy, railing and calumny actively denigrated and misrepresented his services [...] exhibiting monstrous ingratitude" (Historical Memory on Azylo D'Infancia Desvalida da Cidade da Horta, 1884, p. 25). Father João Pedro d'Ávila himself provided the following reasons for resigning: "not only because his strength does not allow it, but also due to his fears that this administration may compromise him, as well as for personal reasons" (Historical Memory on Azylo D'Infancia Desvalida da Cidade da Horta, 1884, p. 25). However, his resignation was not accepted by Civil Governor Santa Rita. Moreover, certificates requested by Father João Pedro d'Ávila that confirmed his exemplary moral, religious and political behavior were provided by the Civil Governor of the district of Horta on June 16, 1865 (Historical Memory on Azylo D'Infancia Desvalida da Cidade da Horta, 1884, pp. 27-28), and by the Ecclesiastical Ombudsman on June 26, 1865 (Historical Memory on Azylo D'Infancia Desvalida da Cidade da Horta, 1884, p. 29). On May 20, 1867, King Dom Luiz appointed him "chevalier of the Military Order of Our Lady Conception of Villa Viçosa" (Historical Memory on Azylo D'Infancia Desvalida da Cidade da Horta, 1884, p. 30) for services rendered to the Church and the State, "particularly for the great dedication and unselfishness he has shown in his administration of the asylum for underprivileged girls established in that city" (Historical Memory on Azylo D'Infancia Desvalida da Cidade da Horta, 1884, p. 29).

In 1872, it was announced that the Sociedade Amor da Pátria (Note 1) might replace the Brotherhood in the management of the Asylum. What might have led to this announcement?

The initial formal proposal was made on February 29, 1872, in a letter written by Councilor António José Vieira Santa Rita, the Civil Governor of the District of Horta, to the President of the Asylum, Father João Pedro d'Ávila. In the letter, the Civil Governor, who previously had always supported Father d'Ávila, asked him to reconsider the role of Irmandade de Santo António de Pádua da Cidade da Horta and suggested that the Asylum's management be transferred to the Sociedade Amor da Pátria through modification of the Statutes due to the "precarious circumstances faced by the Children's Asylum, because I have no hope that it will have an income that meets its needs" (Letter of the Civil Governor proposing the transfer of Asylum's management to Sociedade Amor da Pátria, in Correspondence Found of 1872 on Sociedade Amor da Pátria).

The proposal continued to be presented during the months of March and April, 1872. According to the pamphlet, the Civil Governor attempted to soften his proposal and explained that: "being aware of the willingness on the part of Sociedade Amor da Patria, I begged its protection on behalf of the Asylum, and if the conditions it imposes are not acceptable or accepted by the Brotherhood of S. Antonio, nothing can be done and everything will remain as it was" (March 10, 1872).

Following this proposal, the Civil Governor reported on March 19 that the President had informed him that the legacy in registrations that the Asylum was entitled to "would only be enough to support approximately 12 or 13 asylees". Therefore, the Civil Governor restated his proposal and argued that transferring the Asylum's management to Sociedade Amor da Pátria might allow more asylees to be admitted.

After consulting Sociedade Amor da Pátria, specific conditions were issued, which were referred to in the March 14, 1872, minutes of the members' assembly of Sociedade Amor da Pátria (with 18 members present):

It shall have the entire management, which will be regulated in statutes made by its general assembly. These statutes shall clearly define the composition, appointment and duties of the asylum's Board of Directors, the duties of employees, the required bookkeeping, ways to receive and manage and obligations inherent in Divine worship, and in general all that can contribute to improving the physical, moral and religious education of the asylees. $=$ That, accordingly, the statutes will designate a Committee of three respectable ladies, invited annually by the Board of Directors to internally manage the same Asylum. [...] the society accepts this incumbency only when the circumstance indicated by His Excellency occurs and the respective Brotherhood decides to discontinue its management (Letter of the Civil Governor regarding the transfer of the Asylum's Management to Sociedade Amor da Pátria, March 19, in Correspondence Found of 1872 on Sociedade Amor da Pátria).

This request was followed by an exchange of correspondence in local newspapers (Note 2), which includes an exchange between Father d'Ávila and a journalist of the newspaper $O$ Fayalense in which each justifies their positions on the condition of the Asylum and the role played by the Brotherhood. 
The journalist noted the opportunities provided by the substantial improvement of the Asylum's budget, stressing that the Administrative Board acknowledged the dependence on extraordinary income in its 1870-1871 budget (Historical Memory on Azylo D'Infancia Desvalida da Cidade da Horta, 1884, p. 46) that would be possible if it were managed by Sociedade Amor da Pátria. However, for Father d'Ávila, "the facts prove that the asylum has always paid its expenses and has always been able to balance its accounts, and these facts are indisputable" (p. 52). He based his argument on the claim that "establishments such as ours always have the blessing of Providence, and our asylum provides evidence for this assertion. The necessary resources have always materialized without the need to subject the administration of the asylum to humiliating conditions" (p. 42).

Despite the fact that Father d'Ávila wished to convey the image that the Asylum was self-sufficient, in January 27, 1870, he also thanked the President of Caixa Económica Fayalense for "the great alms that has just been made to this pious and humanitarian establishment, which assisted in meeting the never-ending expenses when it was in deep trouble" (Appreciation of a donation from the Association of Caixa Económica Fayalense, January 27, 1870, in Correspondence Issued from Asylo de Infância Desvalida. From 26-5-1862 to 30-7-1870), which supports the claim that the financial situation of the Asylum was precarious.

Although, in 1872, the number of asylees (11) was at its lowest since its establishment, subsequently there was a financial breathing space in which the Asylum obtained the right to a higher cash legacy that enabled it to increase the number of asylees to 19 (Lemos, 1958).

As a result, President João Pedro d'Ávila, and the Brotherhood eventually rejected the proposal, stating that:

The brotherhood did not want to commit suicide and therefore it could not assume the slightest responsibility.

I therefore have the conviction, Mr. Journalist, that if there is any serious responsibility for this problem, it cannot be attributed to me or to the brotherhood, but to those who are able to benefit needy children but fail to do so because they prefer to yield to the display of power rather than to the impulses of genuine charity (Historical Memory on Azylo D'Infancia Desvalida da Cidade Da Horta, 1884, p. 54).

Finally, at the conclusion of this process, Sociedade Amor da Pátria delivered one additional substantial donation to the Asylum on April 11, 1872 (Information of Sociedade Amor da Pátria of the attribution of a donation, in Correspondence Found of 1872 on Sociedade Amor da Pátria).

In the same year of 1872, Governor Santa Rita, who was in favor of the entrance of Sociedade Amor da Pátria in the management of the Asylum during this process, nonetheless praised President João Pedro d'Ávila:

$[\ldots]$ in that establishment there has always been the highest possible order and cleanliness, and its accounts and bookkeeping are all up to date. [...] Reverend João Pedro d'Avila, who remains in charge of the management of this establishment, is worthy of special mention due to the great zeal and disinterest he has always displayed in managing it, and his free services to the church (Report of the Governor Santa Rita to the Bishop of Angra, dated December 21, 1872, in Historical Memory on Azylo D'Infancia Desvalida da Cidade da Horta, 1884, p. 67).

His praise was supported by that of others. For example, the Bishop of Angra highly complimented Father d'Ávila on January 14, 1873, and the President and Members of the Horta City Council attested to his exemplary moral, religious and political behavior on December 19,1873, recognizing that he sought the "enhancement" of the Asylum (Historical Memory on Azylo D'Infancia Desvalida da Cidade da Horta, 1884, p. 62).

However, Civil Governor Santa Rita left office on October 11, 1877, and the new Civil Governor who took office on January 29, 1878, questioned the actions of the Board of Directors chaired by Father d'Ávila:

[...] the administrative board should, under Article 8 of that Asylum's Regulation, ordinarily meet once a month, and in particular at every time thought convenient, and because I have been informed (certainly for reasons unrelated to the good will of Your Excellency) that this useful regulatory prescription has not been followed, I hereby request that Your Excellency inform me of the reasons for that omission. = Likewise, I wish that Your Excellency inform me of the names of the current lady inspectors that the board appoints in accordance with no. 3 of Article 7. = Considering the high zeal that Your Excellency has always shown in the administration of Asylum, I expect a reply as soon as possible (Letter of the Civil Governor requesting information, in Copy of Letters of Confraria de Santo António e Asylo de Infância Desvalida. From Abril 1872 to 14/6/1878).

In reply to the January 30 letter of the President, in which he tried to resolve the doubts raised, the new Civil Governor issued several instructions to the Board of Directors on the basis of his authority (Information of the Civil Governor, in Copy of the Letters of Confraria de Santo António e Asylo de Infância Desvalida. From Abril 1872 to $14 / 6 / 1878$ ).

The Civil Governor's letter had immediate consequences. On February 10, 1878, the Board of Directors 
immediately appointed a lady inspector for an unfilled position and replaced a deceased board member "by superior order" (Replacement of a board member, February 14, 1878, in Copy of Letters of Confraria de Santo António e Asylo de Infância Desvalida. From Abril 1872 to 14/6/1878).

The process ultimately culminated in the dismissal of Father d'Ávila as President and Chaplain of the Asylum (Permits of February 3 and February 8, 1879, respectively):

$[\ldots]$ when at the beginning of 1879 , he saw that the personal war persisted and that the calumny had assumed gigantic proportions. [...]

[the new Governor] failed to follow the course of his noble predecessor, Santa Rita, paying heed to many intrigues and falsehoods (Historical Memory on Azylo D'Infancia Desvalida da Cidade da Horta, 1884, p. 68).

However, on December 28, 1883, the 25th anniversary of the opening of the Asylum was celebrated $(O$ Fayalense of December 23, 1883, year 27, no. 21, p. 3). Because the occasion occurred with the day of Santos Inocentes in the church of Santo António, the guests' lunch was followed by that of the asylees, which the former attended in keeping with tradition. Because the feast day celebrates that biblical story of the killing of the innocents ordered by King Herod, the asylees attended the party dressed in white (Ribeiro, 1998, p. 333). The celebration of the 25th anniversary of the Asylum was extensively documented in the newspaper $O$ Fayalense, which testified to the contributions of Father João Pedro d'Ávila, the first President of the Asylum:

Reverend Avila was received by the president of the committee, who accompanied him at the door of the church, where he was awaited by the regent of the asylum with her pupils. When the innocent children in their white dresses, symbolizing the sincerity of their innocent hearts, approached the old priest to kiss his hand, he could not conceal the emotion he felt and tears fell from his eyes. Visibly moved, he approached the church's chapel, where he prayed $[. .$.

The honorary royal reverend chaplain, Mr. José Verissimo Ribeiro, recounted the history of the twenty-five years of existence of the institution whose foundations were established by councilor Antonio José Vieira Santa Rita and Fathers Henrique da Pureza Greaves and João Pedro d'Avila.

[...] He praised the acts of dedication and the efforts of the first churchwarden, Father João Pedro (O Fayalense of January 6,1884 , year 27 , no. 23, pp. 2-3).

\section{Discussion}

With respect to its primary focus, the present study has examined the role of the Asylum's founding leader, Father João Pedro d'Ávila, who played a crucial role in the establishment of the Asylum.

Father João Pedro d'Ávila was a strong leader who exerted substantial control over the operation of the Asylum both formally and in practice, by hiring and dismissing employees and through his actions as Chaplain overseeing the religious aspects of the Asylum. To some extent, the situation confirms Schein's $(2004,2010)$ claim that the leader, particularly the leader/founder, plays a central role in establishing an organizational culture.

However, the scope of President João Pedro d'Ávila actions was limited by their sociohistorical context. Limitations included the need to identify sources of funding; the need to maintain positive relationships with the Civil Governor and respect his preeminent role in the Asylum's internal affairs; the preservation of a positive public image; the search for religious, legal, and managerial legitimacy through his appointment as President by the Civil Governor and the instatement of the Administrative Board; and the external and internal regulatory and legal framework provided by the 1860 Statutes and the 1876 Regulations governing the operation of the Asylum.

In particular, with respect to the relationship with the Civil Governor, the Civil Governor was the dominant party. When a new Civil Governor took office on January 29, 1878, the actions of the Administrative Board chaired by Father d'Ávila were questioned for failing to follow regulations, and the new Governor asked for clarification. After the President responded in an attempt to resolve the problem, the Civil Governor subsequently proposed that several procedures be implemented, which rapidly culminated in the resignation of Father d'Ávila as President and Chaplain of the Asylum in 1879.

Thus, factors that were external to the organization influenced its operation and the control exerted by these factors was central to understanding the dynamics of the organization. In the process of cultural (re)configuration, organizational culture is the result of the interaction between structure and action, between the internal and external environment of the organization, in the context of a diachronic dynamics for a particular spatial and temporal context that is socially and historically constructed (Torres, 2004, 2006, 2011).

Consequently, the management of an organization cannot be fully directed, guided or controlled, but always involves aspects that are contingent and indeterminate, as illustrated by the actions of President João Pedro 
d'Ávila who was a strong leader who also had the institutional support of the Civil Governor António José Vieira Santa Rita.

In summary, the action of the founding leader in the establishment of an organizational culture is conditioned by its internal and external environments, and contingent factors influence organizational leadership. As Alvesson (2013) notes, "understanding leadership calls for careful consideration of the social context in which processes of leadership take place [...] This context includes the societal, occupational and organizational - which all frame specific leader-follower interactions" (p. 100). "Understanding leadership calls for the consideration of social process and cultural context; that is, descriptions must be relatively rich or thick" (p. 111). One of the key factors that successful leadership must consider in taking action is the process obtaining permanent legitimacy in diverse domains.

\section{Acknowledgments}

I thank the Board of Directors of Casa de Infância de Santo António (the successor organization of Asilo de Infância Desvalida da Horta) and Board Presidents Dionísio Rocha and Tomás Rocha, in particular, for providing access to the organization's archives.

\section{References}

Alvesson, M. (2013). Understanding organizational culture (2nd ed.). London, UK: SAGE Publications.

Bardin, L. (1995). Análise de conteúdo. Lisbon, Portugal: Edições 70.

Historical memory of azylo d'infancia desvalida da cidade da Horta. (1884). Horta, Azores: Typographia de V. A. L. Silveira.

Lemos, R. R. G. (1958). Asilo de Infância Desvalida da Horta 1858-1958. Manuscript celebrating a century of existence.

Lima, M. (1981). Anais do município da Horta (História da ilha do Faial). East Providence, RI: A \& H Printing, Inc.

Macedo, A. L. S. (1981). História das quatro ilhas que formam o Distrito da Horta (Vol. II). Angra do Heroísmo, Portugal: Direç̧ão Regional dos Assuntos Culturais da Secretaria Regional da Educação e Cultura da Região Autónoma dos Açores.

O Fayalense of December 23, 1883, year 27, no. 21, p. 3 .

O Fayalense of January 6, 1884, year 27, no. 23, pp. 2-3.

Ribeiro, J. A. (1998). Os expostos no Faial durante o século XIX. In O Faial e a periferia açoriana nos séculos $X V$ a XX (pp. 325-337). Horta, Azores: Núcleo Cultural da Horta.

Schein, E. H. (2004). Organizational culture and leadership (3rd ed.). San Francisco, CA: Jossey-Bass.

Schein, E. H. (2010). Organizational culture and leadership (4th ed.). San Francisco, CA: Jossey-Bass.

Serpa, S. (2013). Celebrações e linguagem na imagem do Asilo de Infância Desvalida da Horta, Portugal, 1858-1910. Revista de Ciências Humanas, 47, 331-343. http://dx.doi.org/10.5007/2178-4582.2013 v47n2p331

Smircich, L. (1983). Concepts of culture and organizational analysis. Administrative Science Quarterly, 28, 339-358. http://dx.doi.org/10.2307/2392246

Torres, L. L. (2006). Cultura organizacional em contexto escolar. In L. C. Lima (Ed.), Compreender a escola. Perspectivas de análise organizacional (pp. 133-195). Porto, Portugal: Edições ASA.

Torres, L. L. (2011). Cultura organizacional em contexto escolar. In L. C. Lima (Ed.), Perspectivas de análise organizacional das escolas (pp. 109-152). Vila Nova de Gaia, Portugal: Fundação Manuel Leão.

Torres, L. M. L. (2004). Cultura organizacional em contexto educativo. Sedimentos culturais e processos de construção do simbólico numa escola secundária. Braga, Portugal: Centro de Investigação em Educação do Instituto de Educação e Psicologia da Universidade do Minho. 


\section{Notes}

Note 1. Lima (1981) states that the Sociedade Amor da Pátria "was founded on November 28, 1859" (p. 506). "To tell the truth, the current club Amor da Pátria was not initially specifically a recreational society, but merely a Masonic lodge similar to many that emerged at the time in the shade, like mushrooms, on every corner of Horta (p. 507)". The Society engaged in other charitable actions; for example, the Society financially supported Asilo da Infância Desvalida, either directly or through Caixa Económica Fayalense.

Note 2. The correspondence referred to was found in the archives of the institution and the journalistic correspondence transcribed in Memoria historica sobre o azylo d'infancia desvalida da cidade da Horta, 1884.

\section{Appendix}

\section{Documents of Asilo de Infância Desvalida da Horta:}

Copy of Letters of Confraria de Santo António e Asylo de Infância Desvalida. From Abril 1872 to 14/6/1878.

Correspondence Found of 1872 on Sociedade Amor da Pátria.

Correspondence Issued from Asylo de Infância Desvalida. From 26-5-1862 to 30-7-1870.

Statutes of Confraria de Sto. António e Azylo de Infância Desvalida. January 10, 1876. (include: Statutes of Confraria de Sto. Antonio e Azylo de Infancia Desvalida da cidade da Horta, of 1860, and the internal Regulation of Azylo da infancia desvalida, annexo á irmandade de Santo Antonio de Padua, erecta no extincto convento do mesmo Santo, na cidade da Horta, da ilha do Fayal, of 1876).

Record of Letters received at Asylo de Infância Desvalida. From 1858 to 1862.

\section{Copyrights}

Copyright for this article is retained by the author(s), with first publication rights granted to the journal.

This is an open-access article distributed under the terms and conditions of the Creative Commons Attribution license (http://creativecommons.org/licenses/by/3.0/). 